\title{
Conditioning and coating of Urochloa brizantha seeds associated with inoculation of Bacillus subtilis ${ }^{1}$
}

\author{
Antônio Emilio Rodrigues Manrique ${ }^{2}$, Rita de Cássia Lima Mazzuchelli², \\ Ademir Sergio Ferreira Araujo ${ }^{3}$, Fabio Fernando de Araujo ${ }^{2}$
}

\section{ABSTRACT}

Technological advances for improving the sowing stage of forage plants are important because, besides increasing the operation efficiency, they may also positively affect the plant growth. This study aimed to evaluate the inoculation of Bacillus subtilis in Urochloa brizantha seeds, using coating, physiological conditioning and storage procedures, as well as to observe its effects on seed storage and plant growth. A completely randomized design, in a $2 \times 3 \times 5+1$ factorial scheme [two inoculation procedures (coating and conditioning), three inoculants (B. subtilis AP-3, B. subtilis PRBS-1 and without bacteria), five storage periods $(0,30$, 60, 90 and 120 days) and control (bare seeds)], with five replicates, was used. Two lots of $U$. brizantha seeds were used, characterized as being of higher and lower viability. After the treatments, part of the seeds was employed to evaluate the plant growth promotion in a greenhouse, during 180 days, while the remaining portion was stored at a temperature of $25^{\circ} \mathrm{C}$, with the seed germination being evaluated every 30 days, for 120 days. The physiological conditioning showed the best performance in the evaluations carried out for $U$. brizantha seeds with B. subtilis. The coating and conditioning of the $U$. brizantha seeds with lower viability, both with and without the inoculation of bacteria, increases the shoot mass of plants after 180 days of growth.

KEYWORDS: Seed inoculation, rhizobacteria, germination.

\section{INTRODUCTION}

In Brazil, the area cultivated with forages occupies about 150 million hectares (IBGE 2017), where the genus Urochloa spp. (Brachiaria) is present. However, agricultural practices for improving the quantity and quality of forages are necessary to increase the animal productivity (Silva et al. 2008). Thus, grasses seeds should exhibit a

\section{RESUMO}

Condicionamento e revestimento de sementes de Urochloa brizanta associados à inoculação com Bacillus subtilis

Avanços tecnológicos para melhorar a etapa de semeadura de forrageiras são importantes, pois, além de aumentarem a eficiência na operação, podem proporcionar ganhos no crescimento da planta. Objetivou-se avaliar a inoculação de Bacillus subtilis em sementes de Urochloa brizantha, utilizando-se procedimentos de revestimento, condicionamento fisiológico e armazenamento, bem como seus efeitos na germinação e no crescimento das plantas. Utilizou-se delineamento inteiramente casualizado, em esquema fatorial $2 \times 3 \times 5+1$ [dois procedimentos de inoculação (revestimento e condicionamento), três inoculantes (B. subtilis AP-3, B. subtilis PRBS-1 e sem bactérias), cinco períodos de armazenamento $(0,30,60,90$ e 120 dias) e controle (sementes nuas)], com cinco repetições. Foram utilizados dois lotes de sementes de U. brizantha, caracterizados como de maior e menor viabilidade. Após os tratamentos, parte das sementes foi utilizada para avaliar a promoção de crescimento de plantas em casa-de-vegetação, durante 180 dias, e o restante foi armazenado sob temperatura de $15^{\circ} \mathrm{C}$, com avaliação da germinação a cada 30 dias, durante 120 dias. $\mathrm{O}$ condicionamento fisiológico apresentou melhor desempenho nas avaliações efetuadas para sementes de $U$. brizantha $\operatorname{com} B$. subtilis. O revestimento e o condicionamento nas sementes de $U$. brizantha com menor viabilidade, com e sem inoculação de bactérias, aumenta a massa da parte aérea nas plantas após 180 dias de crescimento.

PALAVRAS-CHAVE: Inoculação de sementes, rizobactérias, germinação.

high germination, what results in a vigorous seedling growth, and, in turn, this provides a suitable soil cover and inhibits weed species.

Adding value to Urochloa spp. seeds by using technology for seed processing, such as seed coating and conditioning, can provide a unique selling point in an increasingly competitive market. Seed coating is the deposition of inert and adhesive materials on the seed surface, with or without modification of

1. Received: Oct. 22, 2018. Accepted: June 06, 2019. Published: Oct. 10, 2019. DOI: 10.1590/1983-40632019v4955536.

2. Universidade do Oeste Paulista, Presidente Prudente, SP, Brasil.E-mail/ORCID: aer_manrique@hotmail.com/ 0000-0003-1455-6854, rita@unoeste.br/0000-0002-6299-9628, fabio@unoeste.br/0000-0002-4614-9260.

3. Universidade Federal do Piauí, Teresina, PI, Brasil. E-mail/ORCID: asfaruaj@yahoo.com.br/0000-0002-3212-3852. 
the seed shape and size (Silva et al. 2002), while in conditioning seeds are soaked with a chemical or biological solution for a certain period of time (Batista et al. 2016). Both techniques may be used to introduce chemical or biological materials that can benefit seeds (Santos et al. 2010). The use of coated or conditioned seeds facilitates sowing by increasing the sanity of the seeds, what, in turn, leads to an improved seedling establishment, allowing the incorporation of nutrients, growth regulators and other inputs (Silva et al. 2002, Bonome et al. 2017). However, Santos et al. (2011) state that techniques such as seed coating, despite being a method used to increase the pasture productivity, may cause inhibition in the germination of Urochloa brizantha.

The plant growth-promoting rhizobacteria that inhabit the soil are isolated from the rhizosphere of several cultivated plants. Among the most studied genera are Bacillus, Pseudomonas, Azospirillum and Rhizobium. The effects of these microorganisms on the plant development are broad and include beneficial effects on seed germination, seedling emergence and plant growth (Figueiredo et al. 2010).

There are few studies about the inoculation of Brachiaria seeds with plant growth-promoting rhizobacteria. For instance, Araujo et al. (2012a) concluded that the inoculation of Bacillus sp. in seeds of $U$. brizantha promotes the growth of plants. In a study carried out with other grasses, the production of hormones by rhizobacteria changed the root morphology and increased the biomass, thus increasing the soil exploration capacity (Malik et al. 1997). Araujo (2008) evaluated the inoculation of Bacillus subtilis in different plant species and showed that the inoculation significantly increased the nitrogen content in maize leaf tissue, even though the introduced bacterial species is not known as diazotrophic. In addition to effects on plant growth, other benefits related to the inoculation of $B$. subtilis may be found in disease management, such as nematode control (Morgado et al. 2015).

When inoculating microorganisms in seeds, it is important to ensure that they have enough bacteria for a greater process efficiency. Following this, a study was conducted, wherein several techniques for bacterial inoculation in seeds were evaluated, such as the use of suspensions, pastes, peat or encapsulation (Walker et al. 2004). Seed coating or conditioning techniques can ensure the highest concentrations of bacteria in the seed. Applying beneficial microorganisms to the seed through either conditioning or coating may further enhance the establishment of the crop, particularly if the applied microorganisms settle in the rhizosphere, and subsequently contribute to the long-term plant health or to the promotion of plant growth (Bennett \& Whipps 2008).

Seed storage is a very important stage in the seed production process and, in the case of $U$. brizantha, other aspects should also be explored, such as dormancy and seed viability (Novembre et al. 2006). In addition, it is necessary to evaluate if the introduction of chemical and biological agents may affect the germination and emergence speed of the U. brizantha seedlings (Santos et al. 2010).

Thus, this study aimed to evaluate the effect of the inoculation of $B$. subtilis on $U$. brizantha seeds using either coating or osmotic conditioning, as well as the effects of the inoculation on germination, plant development and seed storage.

\section{MATERIAL AND METHODS}

The experiments were conducted from September 2016 to June 2017. Non-scarified seeds of U. brizantha (Hochst ex A. Rich.) Stapf. 'Marandu' were used from two lots (1 and 2) with lower and higher viability, respectively, based on a tetrazolium test carried out previously (Novembre 2006). Two strains of B. subtilis (PRBS-1 and AP-3) isolated from an agricultural soil and described in Araujo et al. (2005) were used in this study.

For the seed treatment, initially, B. subtilis was multiplied in a culture medium for five days. Afterwards, the cells were separated by centrifugation $(5,000 \times \mathrm{g})$ and resuspended in water. All suspensions were adjusted to $10^{8}$ colony forming units (CFU) per $\mathrm{mL}$. Initially, the seed coating was carried out using $200 \mathrm{~g}$ of $U$. brizantha seeds and $50 \mathrm{~mL}$ of bacterial cell suspension with $0.75 \mathrm{~g}$ of methyl cellulose, which were mixed in a rotary drum. During mixing, $200 \mathrm{~g}$ of inert talc were added to impart the uniformity in the coating. To perform the osmotic conditioning of the seeds, $200 \mathrm{~g}$ of seeds were packed in an Erlenmeyer flask and immersed with $50 \mathrm{~mL}$ of bacterial cell suspension with $0.425 \mathrm{~g}$ of sodium chloride. The vials were stirred $(120 \mathrm{rpm})$ for $12 \mathrm{~h}$, at $25{ }^{\circ} \mathrm{C}$. Finally, the seeds were dried for $24 \mathrm{~h}$, at $30^{\circ} \mathrm{C}$. In parallel, treatments with seed coating and conditioning were conducted using sterilized water, instead of bacterial 
suspensions, and these were used as control. All treated seeds were stored under a temperature of $15^{\circ} \mathrm{C}$, for 120 days.

The moisture in the seed environment was controlled, and $15 \%$ of humidity for conditioning and $12 \%$ for coating (Brasil 2009) were maintained. Seeds were collected every 30 days for germination evaluation.

The experiment consisted of a $2 \times 3 \times 5+1$ factorial scheme, represented by two seed conditions (coated and conditioned), three inoculants (B. subtilis AP-3, B. subtilis PRBS-1 and without bacteria), five storage periods $(0,30,60,90$ and 120 days) and control (bare seeds), in a completely randomized design, with four replicates.

The variables seed germination percentage and germination rate index were evaluated. In the laboratory, for the germination tests, transparent plastic boxes (gerbox type) were used to house four replicates of 100 seeds on blotter paper (moistened with water 2.5 times the weight of the paper). Afterwards, the boxes were transferred to a germination chamber (BOD). Plants were regulated with alternating light and dark periods $(8 \mathrm{~h}$ and $16 \mathrm{~h}$, respectively) and alternating temperatures of $15{ }^{\circ} \mathrm{C}$ and $35^{\circ} \mathrm{C}$. The number of germinated seeds, as well as the number of normal seedlings, were determined for 21 days with daily ratings and used to calculate the germination percentage and the germination rate index (Brasil 2009).

An experiment was also conducted in a greenhouse, for 180 days, to evaluate the $U$. brizantha 'Marandu' growth, using the seeds after the treatments previously described, prior to storage. The experimental design was a $2 \times 3 \times 5+1$ factorial scheme, represented by two seed conditions (coated and conditioned) and three treatments (B. subtilis AP-3, B. subtilis PRBS-1 and without bacteria), with five replications.

To fill the pots, $4 \mathrm{~kg}$ of a Dystroferric Red Argisol were collected at the $0-20 \mathrm{~cm}$ layer. The soil field capacity was determined in the laboratory. Ten seeds per pot were used for sowing. After the emergence of the plants, thinning was done, leaving two plants per pot. The pots were irrigated daily to maintain the soil moisture near the field capacity, using the gravimetric method. The experimental period started with the standardization cut (42 days after sowing).

At the end of the experiment (180 days after sowing), the shoot dry mass was obtained after the final cutting of the plants. Roots were also collected and washed, and both were oven dried at $65^{\circ} \mathrm{C}$, to obtain the dry mass.

Analyses of variance and F-tests at $5 \%$ of significance were used to estimate and test the effects of the treatments. The means of the treatments were compared by the Tukey test (5\%), and the Dunnett test $(5 \%)$ was used to compare each one of the treated levels with the control. Polynomial regression was also used for analyzing the response of the treatments over the storage time. All analyses were performed in the Assistat software (Silva 2011).

\section{RESULTS AND DISCUSSION}

The evaluation of the seeds of lower viability (lot 1) allowed verifying that the root growth with the conditioning of the seeds seemed promising for dry mass gains, except for those inoculated with $B$. subtilis (PRBS-1). For the shoot dry mass production of $U$. brizantha, the use of seed coating, both with and without bacteria, was superior to the bare seeds (control). When the seed conditioning method was used, only those with bacterial inoculation showed gains in this aspect (Table 1).

In the seeds of greater viability (lot 2), it was verified that the conditioning of seeds combined with the use of the B. subtilis strain AP-3 was the only treatment that increased the mass of the root system of $U$. brizantha, in relation to the control (Table 1).

Table 1. Means ${ }^{1}$ of root and shoot dry mass of Urochloa brizantha (lots 1 and 2) submitted to seed treatments and inoculation with Bacillus subtilis (AP-3 and PRBS-1).

\begin{tabular}{|c|c|c|c|c|}
\hline Lot & Treatments & AP-3 & PRBS-1 & Uninoculated \\
\hline \multirow{6}{*}{1} & & \multicolumn{3}{|c|}{ Root dry mass $\left(\mathrm{g} \mathrm{pl}^{-1}\right)$} \\
\hline & Conditioning & $28.62^{+}$ & 24.30 & $28.4^{+}$ \\
\hline & Coating & 25.54 & 22.51 & 25.6 \\
\hline & & \multicolumn{3}{|c|}{ Shoot dry mass $\left(\mathrm{g} \mathrm{pl}^{-1}\right)$} \\
\hline & Conditioning & $36.44^{+} \mathrm{aA}$ & $34.87^{+} \mathrm{aA}$ & $28.60 \mathrm{bB}$ \\
\hline & Coating & $35.79^{+} \mathrm{aA}$ & $34.82^{+} \mathrm{aA}$ & $34.48^{+} \mathrm{aA}$ \\
\hline \multirow{6}{*}{2} & & \multicolumn{3}{|c|}{ Root dry mass $\left(\mathrm{g} \mathrm{pl}^{-1}\right)$} \\
\hline & Conditioning & $34.42^{+} \mathrm{aA}$ & $30.04 \mathrm{aB}$ & $30.30 \mathrm{aB}$ \\
\hline & Coating & $23.20 \mathrm{bB}$ & $30.56 \mathrm{aA}$ & $22.78 \mathrm{bB}$ \\
\hline & & \multicolumn{3}{|c|}{ Shoot dry mass $\left(\mathrm{g} \mathrm{pl}^{-1}\right)$} \\
\hline & Conditioning & $28.83 \mathrm{~B}$ & $33.91^{+} \mathrm{A}$ & $32.53 \mathrm{~A}$ \\
\hline & Coating & $25.05 \mathrm{~B}$ & $33.94^{+} \mathrm{A}$ & $33.28 \mathrm{~A}$ \\
\hline
\end{tabular}

${ }^{1}$ Means followed by the same uppercase letter in the rows and lowercase letter in the columns do not differ by the Tukey test at $5 \%$ of significance. Means followed by $(+)$ or $(-)$ are respectively higher or lower than the absolute control by the Dunnet test $(\mathrm{p}<0.05)$. 
In the shoot mass production, the inoculation of B. subtilis strain PRBS-1 provided a significant increase in the root mass, using both the seed coating and conditioning.

The coating and conditioning techniques for Urochloa are promising for use in seed processing. In this study, it was observed that, in the less viable lot of seeds, the use of coating and osmotic conditioning techniques with the inoculation of rhizobacteria influenced the growth promotion of the plant shoot, when compared to the bare seeds. Wright et al. (2003) concluded that the simple seed conditioning increases the concentration of bacteria in the seeds, even without inoculation and even after drying beet seeds. Although being a study with a different species, it may suggest that this was the most likely biological phenomenon that happened to explain the growth promotion. This reinforces that the technique is useful for increasing the presence of microorganisms on untreated seeds. Moreover, in this study, it was verified that conditioning and coating, with or without bacterial inoculation, led to significant increases of the biomass of the plant root and shoot in the lot of lower viability, when compared to the bare seeds. This method may be the best technique to treat seeds if they exhibit either a low germination or seed dormancy (Novembre et al. 2006).

The use of seed coatings with rhizobacteria may be considered as a technology with great potential for commercial use (Walker et al. 2004). Studies on beans have shown that coating or conditioning with $B$. subtilis may increase the shoot dry mass production (Junges et al. 2016). The use of Bacillus spp. in conditioning cucumber seeds promoted a greater disease control in young plants and increased the final crop yield (Song et al. 2017). However, studies involving the use of coating or conditioning in forage seeds are still scarce. The association of rhizobacteria with the techniques of coating or conditioning on Brachiaria seeds has shown to be promising, especially in the promotion of shoot mass in plants of higher viability inoculated with $B$. subtilis (PRBS-1). However, the effect of inoculation of $B$. subtilis (AP-3) via conditioning on root growth in this lot can also be highlighted.

In the germination evaluation during the storage period, a lower germination was observed in low viability seeds (lot 1), when compared to the lot 2 (Figure 1). Coating treatments performed on the seeds of the lot 1 did not promote significant changes for significant regression adjustments over the storage time, what also did not happen with the evaluation of the bare seeds (control). It is observed that, in this lot, germination generally increases at 60-90 days and decreases at 120 days. Analyzing the performance of the treatments, it can also be highlighted that conditioning presented values closer to quadratic adjustments, represented in a significant way by the evaluation of the treatment without the bacteria inoculation.

On the other hand, when analyzing the lot of greater viability, it was observed that the bare seeds presented a significant linear adjustment increase for the germination values. Treatments without inoculation presented quadratic adjustments and maximum germination points close to 60 days, whereas the remaining ones had no significant adjustments.

The germination rate index also showed results with similar adjustments to the germination using regression analysis in both lots (Figure 2).

One of the concerns in the use of seed coating or osmotic conditioning is the physiological disturbances that these techniques can promote over the seed storage time (Santos et al. 2010). These authors concluded that seed coating promotes a reduction in the germination and seedling emergence speed of $U$. brizantha 'Marandu' after 12 months of storage. After the evaluation of the two lots in this study, it was determined that these parameters were reduced after 120 days of storage in the treated seeds from the lot of higher viability (Figure 2). The performances of both the coated and conditioned seeds were also observed during the germination of $U$. brizantha, and it was found that conditioned seeds were better for up to 90 days of storage. In conditioning tobacco seeds, the absence of negative effects on germination during 90 days of evaluation was also verified (Caldeira et al. 2014).

Santos et al. (2010) concluded, in a longterm Urochloa seed coat study, that this technique promotes a reduction in the seed germination and germination speed index. However, this technique is important because of the other benefits of this practice, such as facilitating sowing and reducing the incidence of phytopathogens. Most likely the seed dormancy was broken with the storage period, what may be expected with Urochloa, to which aging decreases the seed vigor. In terms of long-term germination loss, the conditioning of Brachiaria 

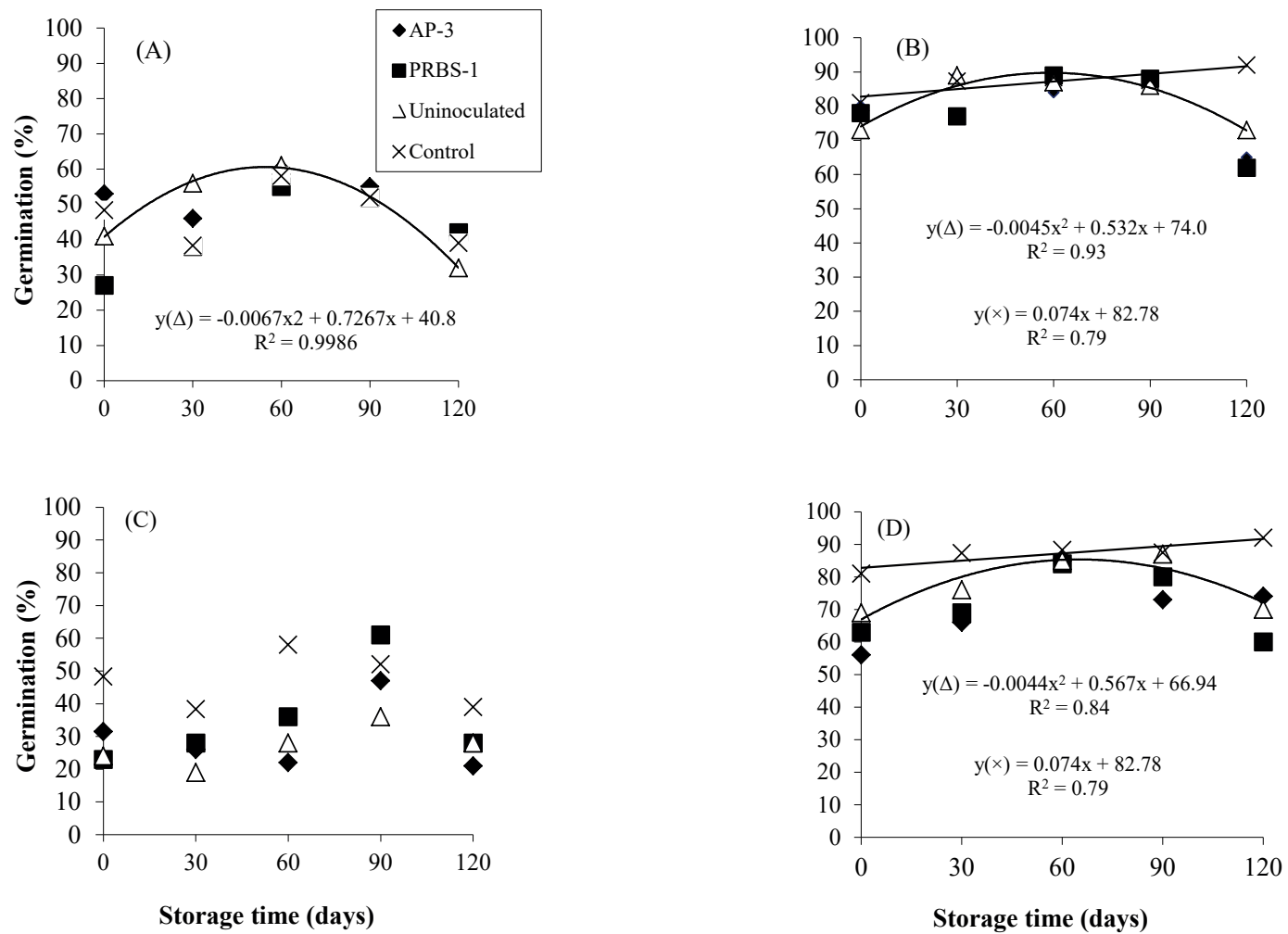

Figure 1. Germination percentage of Urochloa brizantha submitted to seed treatments and inoculation with Bacillus subtilis AP-3 and PRBS-1. A: conditioned seeds/lot 1; B: conditioned seeds/lot 2; C: coated seeds/lot 1; D: coated seeds/lot 2.
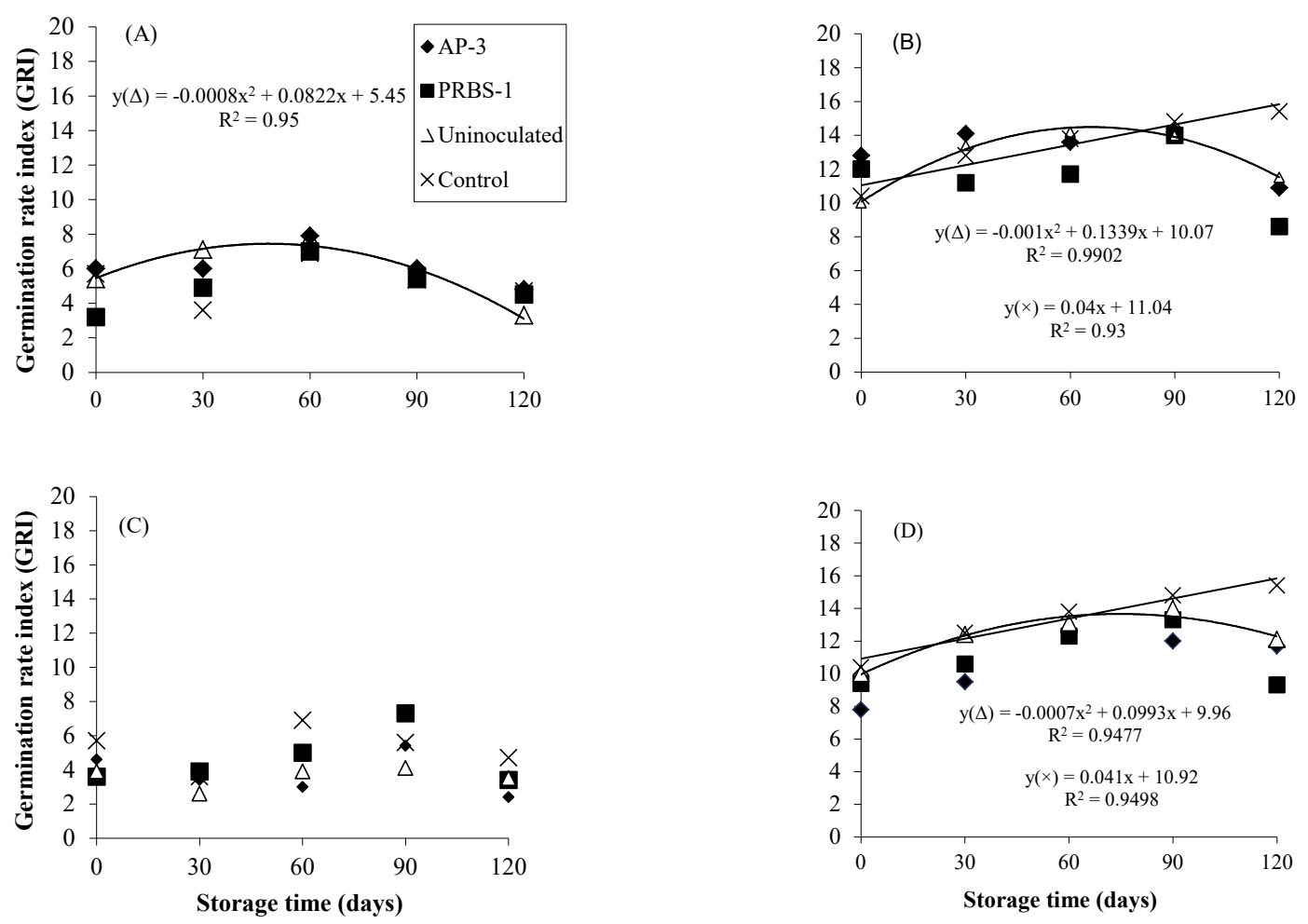

Figure 2. Germination rate index of Urochloa brizantha (lot 2) submitted to seed treatments and inoculation with Bacillus subtilis AP-3 and PRBS-1. A and C: conditioned seeds; B and D: coated seeds. 
seeds showed more promising results than coating for up to 90 days of storage (Figure 1). In order to evaluate the effect of rhizobacteria on bean seeds, El-Mougy \& Abdel-Kader (2008) found no loss of seed germination, but observed a loss of rhizobacteria as pathogen antagonists at 90 days.

The presence of rhizobacteria in the rhizosphere of plants can provide numerous benefits to plants and soil. Urochloa seeds, in both the evaluated lots, were not affected by the presence of bacteria in the first 90 days, and this may stimulate further studies to evaluate the use of this grass to introduce rhizobacteria like B. subtilis in the soil. The introduction of these microorganisms can provide innumerable benefits to the production system, since rhizobacteria are cited as efficient antagonists of pathogens such as fungi (Araujo et al. 2005, Yánez-Mendizábal et al. 2012, Gao et al. 2014). They also provide other indirect benefits such as nutrient solubilization in the soil and reduction of damage caused by abiotic stresses (Ferreira et al. 2018). Bacteria of the genus Bacillus can promote plant growth when inoculated previously on Urochloa seeds (Araujo et al. 2012a). Pastures may also benefit from the inoculation of $B$. subtilis, as rhizobacteria may confer a greater stress on plants (Gagné-Bourque et al. 2016).

The use of rhizobacteria such as B. subtilis may contribute to the sustainability of the system, since these can make the soil suppressive to several pathogens, what may result in an increase in their population over time (Lazzaretti \& Bettiol 1997). This bacterial species also has the ability to colonize the roots by forming a thin biofilm layer on them, which then confers benefits to the plant (Beauregard et al. 2013). The treatment of seeds with $B$. gaemokensi to elicit resistance enables the plants to effectively mount long-term resistance responses against plant pathogens and insects (Song et al. 2017).

The efficient colonization of the root system allows a more favorable competitive situation against other species of microorganisms (Kilian et al. 2000). Verma et al. (2018) showed that endophytic microorganisms like $B$. subtilis are responsible for the modulation of the Urochloa ramosa growth and the protection of plants against fungal diseases. However, the use of rhizobacteria does not always provide the greatest plant growth (Corrêa et al. 2010): some may be indifferent to the inoculation process, while others may consider the bacteria as pathogens, thus impairing their growth.
Forages are permanent crops, thus requiring a great root development, which aids in the seeking of water and nutrients from the deep layers of the soil and promotes the cycling of nutrients (Santos et al. 2007). Consequently, the use of techniques that allow a greater development of these plants is very important, as plants with a greater root volume have higher production conditions, even in adverse climatic conditions. In addition, a root system with broad growth can improve the soil quality, especially when it comes to the structure and accumulation of organic matter (Salton et al. 2004). Seed coating has been the most widely used enhancement in the forage seed trade, as evidenced by the amount of commercial investment to these processes (Simon et al. 1998).

The results showed potential applications of the techniques of conditioning and coating seeds, with or without bacteria, in the different stages of the forage seed processing. Bonome et al. (2017) reported that coating and conditioning on forage ( $U$. brizantha) can also improve sowing operations and serve to introduce other inputs, such as biological agents, that can then associate with the seeds. Most studies on seed conditioning of Urochloa has as a main objective the dormancy breaking to obtain a higher germination pattern and vigor and are evaluated in short storage periods (Ribeiro et al. 2019). Based on the results, it can be stated that seed conditioning and coating with B. subtilis kept the germination profile similar to the bare seeds for about 90 days, considering the seeds of the most viable lot. These results may stimulate further studies with inoculation of other rhizobacteria using coating or conditioning techniques similar to those in the present study. More studies are needed to explore the ability of the introduced microorganisms to colonize the rhizosphere, as well as tests using other forage species and tests involving longer storage times.

\section{CONCLUSIONS}

1. Seed physiological conditioning shows a better performance when inoculating Urochloa brizantha seeds with Bacillus subtilis;

2. Coating and conditioning $U$. brizantha seeds with less viability, both with and without bacteria inoculation, increases the shoot mass in the plants after 180 days of growth;

3 . The use of conditioning or coating reduces the germination after 90 days of storage in seeds of greater viability. 


\section{REFERENCES}

ARAUJO, F. F. Inoculação de sementes com Bacillus subtilis, formulado com farinha de ostras e desenvolvimento de milho, soja e algodão. Ciência e Agrotecnologia, v. 32, n. 2, p. 456-462, 2008.

ARAUJO, F. F.; BRAGANTE, R. J.; BRAGANTE, C. E. Controle genético, químico e biológico de meloidoginose na cultura da soja. Pesquisa Agropecuária Tropical, v. 42, n. 2, p. 220-224, 2012 b.

ARAUJO, F. F.; GUABERTO, L. M.; SILVA, I. D. Bioprospecção de rizobactérias promotoras de crescimento em Brachiaria brizantha. Revista Brasileira de Zootecnia, v. 41, n. 3, p. 521-527, 2012a.

ARAUJO, F. F.; HENNING, A. A.; HUNGRIA, M. Phytohormones and antibiotics produced by Bacillus subtilis and their effects on seed pathogenic fungi and on soybean root development. World Journal of Microbiology and Biotechnology, v. 21, n. 8, p. 1639-1645, 2005.

BATISTA, T. B.; CARDOSO, E. D.; BINOTTI, F. F. D. S.; COSTA, E.; SÁ, M. E. D. Priming and stress under high humidity and temperature on the physiological quality of Brachiaria brizantha cv MG-5 seeds. Acta Scientiarum, v. 38, n. 1, p. 123-127, 2016.

BEAUREGARD, P. B.; CHAI, Y.; VLAMAKIS, H.; LOSICK, R.; KOLTER, R. Bacillus subtilis biofilm induction by plant polysaccharides. Proceedings of the National Academy of Sciences, v. 110. n. 17, p. 16211630, 2013.

BENNETT, A. J.; WHIPPS, J. M. Beneficial microorganism survival on seed, roots and in rhizosphere soil following application to seed during drum priming. Biological Control, v. 44, n. 3, p. 349-361, 2008.

BONOME, L. T. S.; GUIMARÃES, R. M.; OLIVEIRA, J. A.; DOUSSEAU, S. Osmoconditioning of Urochloa brizantha seeds to reduce pelleting negative effects. Brazilian Journal of Agriculture, v. 92, n. 2, p. 87-100, 2017.

BRASIL. Ministério da Agricultura e Reforma Agrária. Regras para análise de sementes. Brasília, DF: SNDA/ DNFU/CLV, 2009.

CALDEIRA, C. M.; CARVALHO, M. L. M.; GUIMARÃES, R. M.; COELHO, S. V. B. Physiological priming and pelleting of tobacco seeds. Seed Science and Technology, v. 42, n. 2, p. 180-189, 2014.

CORRÊA, É. B.; BETTIOL, W.; SUTTON, J. C. Controle biológico da podridão radicular (Pythium aphanidermatum) e promoção de crescimento por Pseudomonas chlororaphis 63-28 e Bacillus subtilis GB03 em alface hidropônica. Summa phytopathologica, v. 36, n. 4, p. 275-281, 2010.

EL-MOUGY, N. S.; ABDEL-KADER, M. M. Long-term activity of bio-priming seed treatment for biological control of faba bean root rot pathogens. Australasian Plant Pathology, v. 37, n. 5, p. 464-471, 2008.

FERREIRA, N.C.; MAZZUCHELLI, R. C. L.; PACHECO, A. C.; ARAUJO, F. F. ; ANTUNES, J. E. L.; ARAUJO, A. S. F. Bacillus subtilis improves maize tolerance to salinity. Ciência Rural, v. 48, n. 8, e20170910, 2018.

FIGUEIREDO, M. V. B.; SELDIN, L.; ARAUJO, F. F.; MARIANO, R. L. R. Plant growth promoting rhizobacteria: fundamentals and applications. In: MAHESHWARI, D. K. (ed.). Plant growth and health promoting bacteria. Berlin: Springer-Verlag, 2010. p. 45-68.

GAGNÉ-BOURQUE, F.; BERTRAND, A.; CLAESSENS, A.; ALIFERIS, K. A.; JABAJI, S. Alleviation of drought stress and metabolic changes in Timothy (Phleum pratense L.) colonized with Bacillus subtilis B26. Frontiers in Plant Science, v. 3, n. 7, p. 1-16, 2016.

GAO, X.; HAN, Q.; CHEN, Y.; QIN, H.; HUANG, L.; KANG, Z. Biological control of oilseed rape Sclerotinia stem rot by Bacillus subtilis strain Em7. Biocontrol Science and Technology, v. 24, n. 1, p. 39-52, 2014.

INSTITUTO BRASILEIRO DE GEOGRAFIA E ESTATÍSTICA (IBGE). Censo agropecuário de 2017. 2017. Disponível em: https://censoagro2017.ibge.gov.br/ templates/censo_agro/resultadosagro/pdf/producao.pdf. Acesso em: 10 jan. 2018.

JUNGES, E.; MUNIZ, M. F. B.; BASTOS, B. D. O.; ORUOSKI, P. Biopriming in bean seeds. Acta Agriculturae Scandinavica, v. 63, n. 3, p. 207-214, 2016.

KILIAN, M.; STEINER, U.; KREBS, B.; JUNGE, H.; SCHMIEDEKNECHT, G.; HAIN, R. FZB24 ${ }^{\circledR}$ Bacillus subtilis: mode of action of a microbial agent enhancing plant vitality. Pflanzenschutz-Nachrichten Bayer, v. 1, n. 1, p. 72-93, 2000.

LAZZARETTI, E.; BETTIOL, W. Tratamento de sementes de arroz, trigo, feijão e soja com um produto formulado à base de células e de metabólitos de Bacillus subtilis. Scientia Agricola, v. 54, n. 1-2, p. 89-96, 1997.

MALIK, K. A.; BILAL, R.; MEHNAZ, S.; RASUL, G.; MIRZA, M. S.; ALI, S. Association of nitrogen-fixing plant-growth promoting rhizobacteria (PGPR) with kallar grass and rice. Plant Soil, v. 194, n. 1-2, p. 37-44, 1997.

MORGADO, T. D. T.; GUERRA, J. T.; ARAUJO, F. F.; MAZZUCHELLI, R. D. C. L. Effectiveness and persistence of biological control of nematodes in sugarcane. African Journal of Agricultural Research, v. 10, n. 49, p. 4490-4495, 2015. 
NOVEMBRE, A. D. L. C.; CHAMMA, H. M. C. P.; GOMES, R. B. R. Viabilidade das sementes de braquiária pelo teste de tetrazólio. Revista Brasileira de Sementes, v. 28, n. 2, p. 147-151, 2006.

RIBEIRO, E. C. G.; REIS, R. D. G. E.; VILAR, C. C.; VILAR, F. C. M. Physiological quality of Urochloa brizantha seeds submitted to priming with calcium salts. Pesquisa Agropecuária Tropical, v. 49, e55341, 2019.

SALTON, J. C.; MERCANTE, F. M.; TOMAZI, M.; ZANATTA, J. A.; CONCENÇO, G.; SILVA, W. M.; RETORE, M. Integrated crop-livestock system in tropical Brazil: toward a sustainable production system. Agriculture, Ecosystems \& Environment, v. 190, n. 1, p. 70-79, 2014.

SANTOS, F. C.; OLIVEIRA, J. A.; VON PINHO, E. V. R.; GUIMARÃES, R. M.; VIEIRA, A. R. Tratamento químico, revestimento e armazenamento de sementes de Brachiaria brizantha cv. Marandu. Revista Brasileira de Sementes, v. 32, n. 3, p. 69-78, 2010.

SANTOS, L. D. C.; BENETT, C. G. S.; SILVA, K. S.; SILVA, L. V. Germinação de diferentes tipos de sementes de Brachiaria brizantha cv. BRS Piatã. Bioscience Journal, v. 27, n. 3, p. 420-426, 2011.

SANTOS, R. S. M.; OLIVEIRA, I. P.; MORAIS, R. F.; URQUIAGA, S. C.; BODDEY, R. M.; ALVES, B. J. $\mathrm{R}$. Componentes da parte aérea e raízes de pastagens de Brachiaria spp. em diferentes idades após a reforma, como indicadores de produtividade em ambiente de Cerrado. Pesquisa Agropecuária Topical, v. 37, n. 2, p. 119-124, 2007.

SILVA, H. A. S.; KOEHLER, H. S.; MORAES, A. D.; GUIMARÃES, V. D. A.; HACK, E. C.; CARVALHO, P. C. D. F. Análise da viabilidade econômica da produção de leite a pasto e com suplementos na região dos Campos Gerais - Paraná. Ciência Rural, v. 38, n. 2, p. 445-450, 2008.

SILVA, J. B. C.; SANTOS, P. E.; NASCIMENTO, W. M. Desempenho de sementes peletizadas de alface em função do material cimentante e da temperatura de secagem dos péletes. Horticultura Brasileira, v. 20, n. 1, p. 67-70, 2002.

SILVA, F. A. S. Assistat para o sistema operacional Windows. 2011. Disponível em: http://www.assistat.com/ indexp.html. Acesso em: jan. 2014.

SIMON, U.; HARE, M. D.; KJAERSGAARD, B.; CLIFFORD, P. T. P.; HAMPTON, J. G.; HILL, M. J. Harvest and postharvest management of forage seed crops. In: FAIREY, D. T.; HAMPTON, J. G. (ed.). Forage seed production: temperate species. New York: CAB International, 1997. p. 181-217.

SONG, G. C.; CHOI, H. K.; KIM, Y. S.; CHOI, J. S.; RYU, C. M. Seed defense biopriming with bacterial cyclodipeptides triggers immunity in cucumber and pepper. Scientific Reports, v. 7, e14209, 2017.

VERMA, S. K.; WHITE, J. F. Indigenous endophytic seed bacteria promote seedling development and defend against fungal disease in browntop millet (Urochloa ramosa L.). Journal of Applied Microbiology, v. 124, n. 3, p. 764-778, 2018.

WALKER, R.; ROSSALL, S.; ASHER, M. J. C. Comparison of application methods to prolong the survival of potential biocontrol bacteria on stored sugar-beet seed. Journal of Applied Microbiology, v. 97, n. 2, p. 293-305, 2004.

WRIGHT, B.; ROWSE, H.; WHIPPS, J. M. Microbial population dynamics on seeds during drum and steeping priming. Plant and Soil, v. 255, n. 2, p. 631-640, 2003.

YÁNEZ-MENDIZÁBAL, V.; ZERIOUH, H.; VIÑAS, I.; TORRES, R.; USALL, J.; VICENTE, A.; TEIXIDÓ, N. Biological control of peach brown rot (Monilinia spp.) by Bacillus subtilis CPA-8 is based on production of fengycinlike lipopeptides. European Journal of Plant Pathology, v. 132, n. 4, p. 609-619, 2012. 